\title{
Biology and Control of Indian Jujube (Ziziphus mauritiana): A Weed to Watch in Florida Pastures and Natural Areas ${ }^{1}$
}

\author{
Brent Sellers ${ }^{2}$
}

Indian jujube (Ziziphus mauritiana), also known as Chinese apple, is a large shrub or small tree (Figure 1). The plant is native to South Asia and East Africa, but it has spread to Queensland, Australia, where it is considered a Class 2 Invasive Plant. This designation means the plant is established and has or could have an adverse economic, environmental, or social impact, and management of the plant is subject to control programs conducted by agencies and landowners (Department of Primary Industries and Regional Development 2016).

According to the Atlas of Florida Plants, Indian jujube is also present in Miami-Dade, Broward, and Glades Counties in Florida (Wunderlin et al. 2021). The University of Florida Herbarium has also identified specimens of Indian jujube in Lee County, Florida. These findings suggest this invasive plant may be more widespread than indicated by vouchered herbarium specimens. However, this species is not listed on the Florida Exotic Pest Plant Council List nor the Florida Noxious Weed List. This publication is intended for managers of grazing lands as well as natural areas.

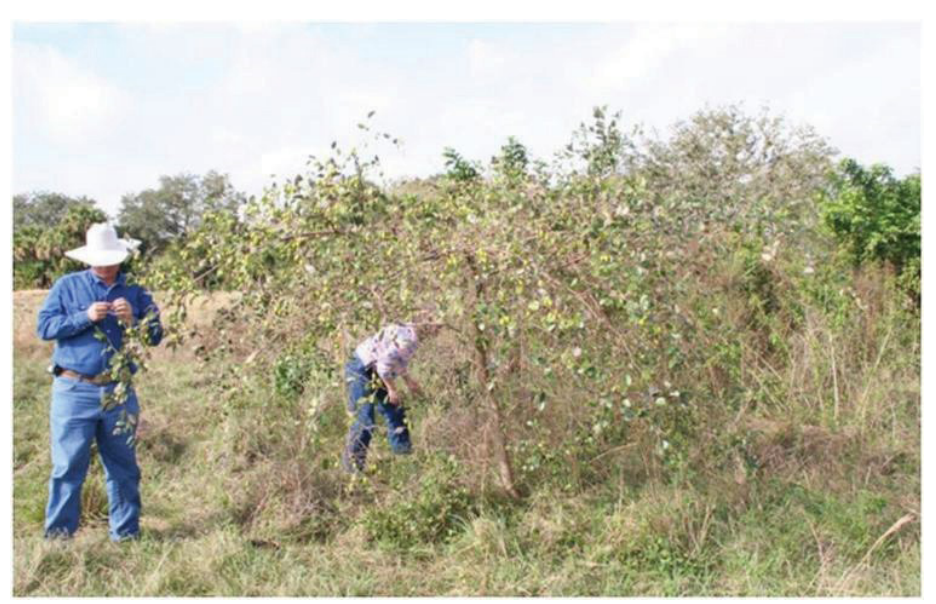

Figure 1. Indian jujube in a pasture near Lakeport, FL. (The man on the left is approximately 6 feet tall.) Several smaller Indian jujube plants were also found in this pasture.

Credits: Brent Sellers, UF/IFAS

\section{Plant Identification}

Indian jujube is a densely branched woody plant with zigzag branches (Figure 2). Mature Indian jujube plants can be as tall as 26 feet with a canopy diameter of at least 30 feet. Branches typically have a leaf and a thorn at each angle. Its ovoid leaves are glossy green above and nearly

1. This document is SSAGR307, one of a series of the Agronomy Department, UF/IFAS Extension. Original publication date August 2008. Revised October 2021. Visit the EDIS website at https://edis.ifas.ufl.edu for the currently supported version of this publication.

2. Brent Sellers, professor, Agronomy Department; UF/IFAS Range Cattle Research and Education Center, Ona, FL 33865.

The use of trade names in this publication is solely for the purpose of providing specific information. UF/IFAS does not guarantee or warranty the products named, and references to them in this publication do not signify our approval to the exclusion of other products of suitable composition.

Use pesticides safely. Read and follow directions on the manufacturer's label.

The Institute of Food and Agricultural Sciences (IFAS) is an Equal Opportunity Institution authorized to provide research, educational information and other services only to individuals and institutions that function with non-discrimination with respect to race, creed, color, religion, age, disability, sex, sexual orientation, marital status, national origin, political opinions or affiliations. For more information on obtaining other UF/IFAS Extension publications, contact your county's UF/IFAS Extension office. U.S. Department of Agriculture, UF/IFAS Extension Service, University of Florida, IFAS, Florida A \& M University Cooperative Extension Program, and Boards of County Commissioners Cooperating. Nick T. Place, dean for UF/IFAS Extension. 
white underneath. The major veins in the leaves are nearly parallel (Figure 3). Over time, the leaves typically become infested with a fungus, causing the leaves to have a yellowmottled appearance above and to turn black below (Figure 4). Flowers of the Indian jujube are small, inconspicuous, and greenish-white, and emit an unpleasant odor.

The fruits are edible and are similar in shape and size to the hog plum (Figure 5), which is native to Florida. The Indian jujube fruits are initially green, but have a yellow to paleorange color when ripe. Seeds are enclosed within a woody endocarp.

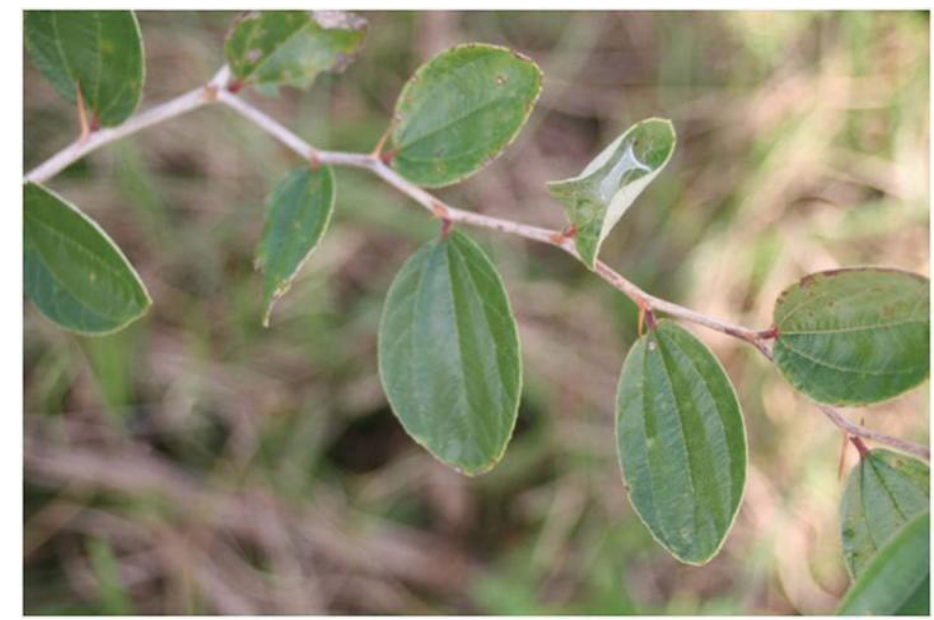

Figure 2. Branches of Indian jujube typically zigzag, with a thorn and leaf at nearly every angle.

Credits: Brent Sellers, UF/IFAS

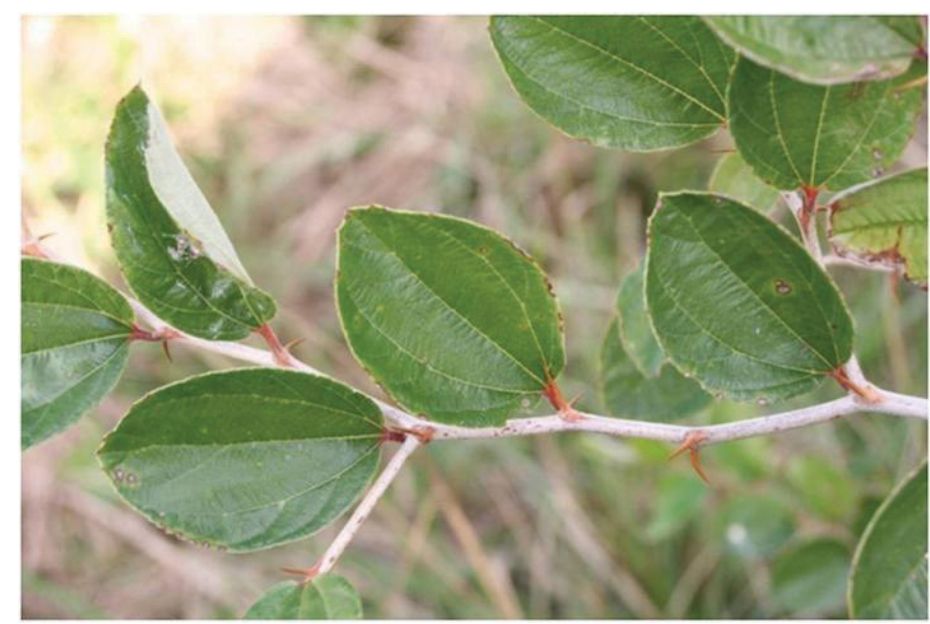

Figure 3. Indian jujube leaves are glossy green above and nearly white below. Note that the major leaf veins are nearly parallel.

Credits: Brent Sellers, UF/IFAS

\section{Habitat and Ecology}

In most cases, Indian jujube is restricted to the drier tropics. During the dry season, these plants typically lose their leaves, but rapid regrowth occurs at the onset of the rainy season. According to researchers in Australia, Indian jujube is capable of growing on a wide range of soil types among various vegetation groups. However, Indian jujube prefers open habitats and does not survive well under the canopy of other trees (Department of Primary Industries and Regional Development 2016).

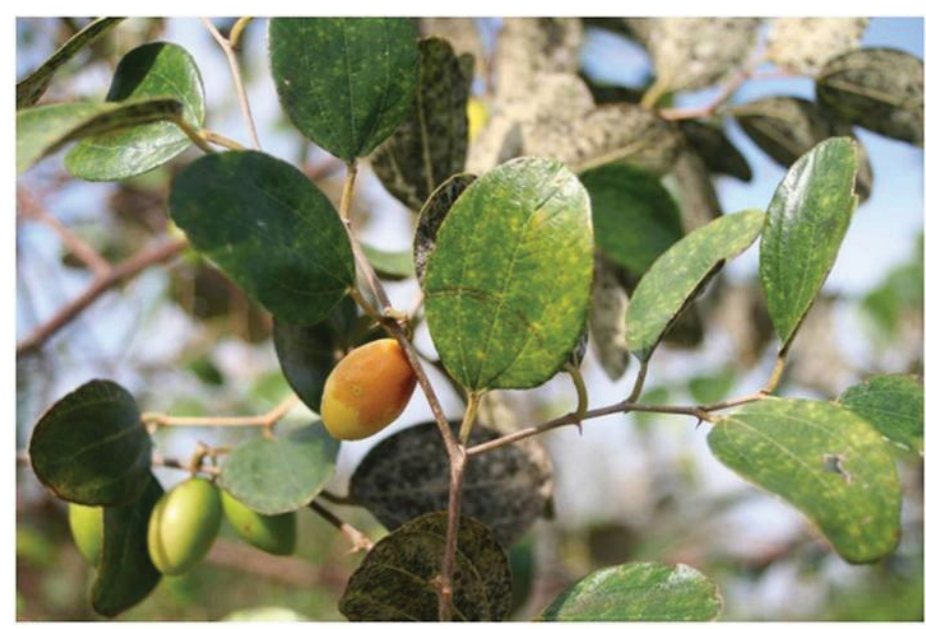

Figure 4. A fungus typically infests the leaves of Indian jujube, giving them a mottled appearance above and a black color below. Credits: Brent Sellers, UF/IFAS

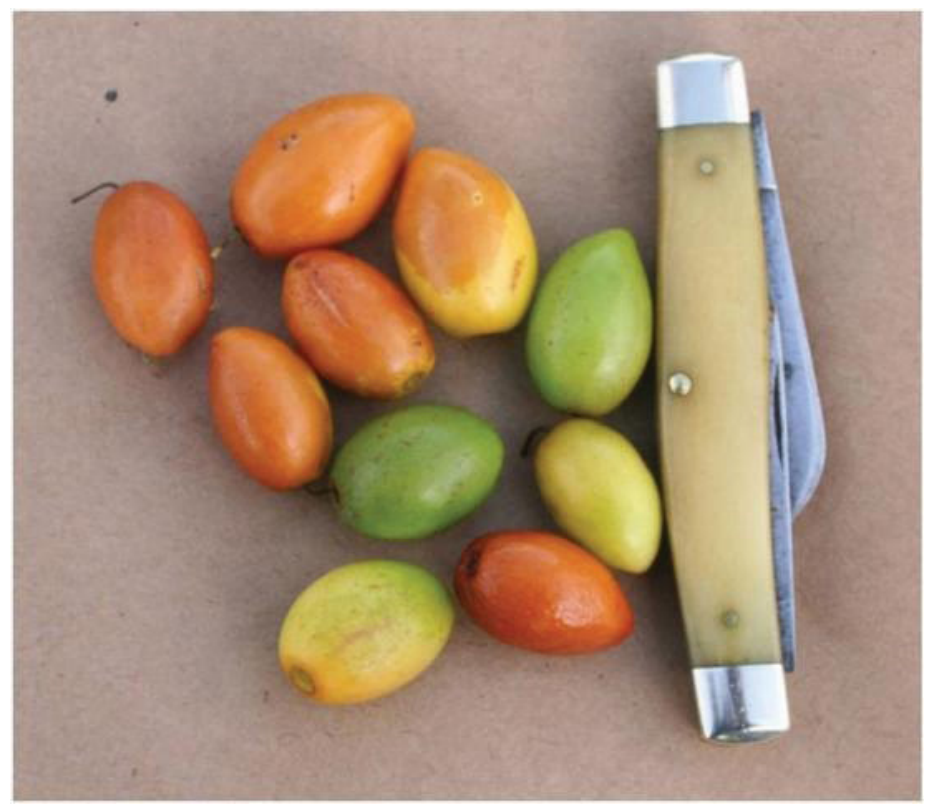

Figure 5. Indian jujube fruits are similar in size and shape to the hog plum, which is native to Florida. Immature Indian jujube fruits are green, changing to yellow, then to reddish-orange when ripe. Credits: Brent Sellers, UF/IFAS

Fruit and seed production is highly variable among Indian jujube plants. However, plants under 5 feet in height typically do not produce fruits (Grice 1998). Large plants (more than 10 feet tall) are capable of producing 5,000 fruits (Grice 1998). Plants in the height range of 5-6.5 feet produced an average of 2-7 fruits per plant. Plants in the range of 6.5-10 feet produced an average of 19-54 fruits per plant (Grice 1998). 
Seedling survival in Australia is extremely low, with $0.002 \%-3.7 \%$ survival. Grice (1998) contends that the critical phase of Indian jujube's life cycle occurs in the first dry season following germination. During the dry season, most seedlings die, and the number of surviving seedlings is governed by the length of the dry season.

\section{Spread}

Dispersal of Indian jujube is primarily through animals. In large infestations within cattle-grazing areas in Australia, an average of 17.5 fruits (woody endocarps) were recovered from cattle dung piles (Grice 1998). Feral swine and birds also likely disperse Indian jujube seeds in Florida, as in Australia.

\section{Control}

Methods for controlling Indian jujube include cut-stump, basal bark, and foliar sprays. Basal bark and cut-stump applications of Vista (fluroxypyr) at a $1 \%$ solution (in oil) or triclopyr-ester (Garlon 4 Ultra, Remedy Ultra, Tahoe 4, etc.) at a $5 \%$ solution (in oil) have been effective in Australia. Foliar sprays of a 3\% v/v triclopyr-ester or glyphosate at the same concentration have also been effective in Australia.

Although Indian jujube is not widespread in Florida, the plant should be recognized early as a potentially invasive one. The spread of this plant in Australia is causing harm in various ecosystems in a climate very similar to that of Florida. For example, dense thickets of Indian jujube in Australia not only displace native plant communities, but also impair the movement of livestock and wildlife. Preventing the spread of this potentially invasive plant in Florida is extremely important.

\section{References}

Department of Primary Industries and Regional Development. 2016. "Chinee Apple Control." Western Australia Agriculture Authority. https://www.agric.wa.gov.au/

herbicides/chinee-apple-control

Grice, A. C. 1998. "Ecology in the Management of Indian Jujube (Ziziphus mauritiana).” Weed Sci. 46:467-474.

Wunderlin, R. P., B. F. Hansen, A. R. Franck, and F. B. Essig. 2021. Atlas of Florida Plants (http://florida.plantatlas. usf.edu/). [S. M. Landry and K. N. Campbell (application development), USF Water Institute.] Institute for Systematic Botany, University of South Florida, Tampa. 